\title{
TEMPERATURE AND HUMIDITY TEST OF THE TELEMETRY TOOL MODELING IN BABY INCUBATOR
}

\author{
Ansor Usman, Hendra Marwazi, Samsul Alam \\ Jurusan Teknik Elektromedik Poltekkes Kemenkes Jakarta II \\ Hang Jebat III / F-3 Jakarta 12120 \\ Email: ansor.usman@gmail.com
}

\begin{abstract}
Modeling tool is made an attempt to help health care in special hospitals for care in obstetrics and perinatology space. This study used temperature setting range is from $34{ }^{\circ} \mathrm{C}$ to $38^{\circ} \mathrm{C}$, while for setting the humidity of the range of $0 \%$ to $100 \%$, is divided into two parts, namely the design of hardware and software. Tests conducted in the Laboratory of the Department of Health Polytechnic Elektromedik Jakarta II. Design manufacture of modules that do get into the telemetry monitoring system applications, where telemetry tool can be used to monitor the value of an object located at a remote distance applied to medical devices, which will be monitored temperature and humidity is a very important part in the incubator tool baby. The results of modeling design includes testing of skin temperature in the incubator, the test measurement of skin temperature and humidity in the telemetry receiver, test measurement of skin temperature on the thermometer, hygrometer humidity in the test measurement. With the results of the five test measurement was still below the threshold of $10 \%$. It can be concluded that the telemetry tool can perform accurate distance measurement, in accordance with the amount of heat generated by the source and the humidity is a tool incubator. This research can be developed to monitor the temperature and humidity with computer based.
\end{abstract}

Keywords: test, incubators, humidity, temperature, threshold, telemetry, health care.

\section{UJI COBA RANCANG BANGUN MODUL PEMODELAN ALAT TELEMETRI SUHU DAN KELEMBABAN PADA ALAT INKUBATOR BAYI}

\begin{abstract}
ABSTRAK
Uji coba alat ini dibuat sebagai upaya untuk dapat membantu pelayanan kesehatan di rumah sakit khusus untuk pelayanan di ruang kebidanan dan perinatologi. Penelitian ini menggunakan metode penelitian rancang bangun Pengaturan suhu adalah dari jangkauan $34^{\circ} \mathrm{C}$ hingga $38^{\circ} \mathrm{C}$, untuk pengaturan kelembaban dari jangkauan $0 \%$ hingga $100 \%$, terbagi atas dua bagian yaitu perancangan perangkat keras dan perangkat lunak. Pengujian dilakukan di Laboratorium Jurusan Teknik Elektromedik Politeknik Kesehatan Jakarta II. Aplikasi sistem telemetri monitoring, dapat digunakan untuk memonitoring nilai dari sebuah objek yang berada pada jarak yang berjauhan diaplikasikan ke dalam alat kesehatan, yang akan dipantau suhu dan kelembabannya merupakan bagian yang sangat penting pada alat inkubator bayi, menggunakan sensor suhu dan kelembaban. Hasil uji coba pemodelan perancangan tersebut meliputi pengujian suhu kulit di inkubator, pengujian pengukuran suhu kulit dan kelembaban di reciever telemetri, pengujian pengukuran suhu kulit di termometer, pengujian pengukuran kelembaban di hygrometer. Dengan hasil dari kelima pengujian pengukuran itu masih di bawah ambang batas $10 \%$. Dengan demikian dapat disimpulkan bahwa alat telemetri dapat melakukan pengukuran jarak jauh dengan akurat, sesuai dengan besaran yang dihasilkan oleh sumber panas dan kelembaban yaitu alat inkubator. Penelitian ini dapat dikembangkan dengan memonitor suhu dan kelembaban dengan berbasis komputer.
\end{abstract}

Keyword : uji coba, inkubator, kelembaban, suhu, ambang batas, telemetri, pelayanan kesehatan 


\section{PENDAHULUAN}

Interaksi teknologi dalam bidang kedokteran hingga saat ini, mengalami perkembangan dan kemajuan. Ditandai dengan berkembang pesatnya alat-alat medis yang dirancang sepraktis mungkin agar penggunaanya lebih mudah dan lebih efisien dalam sasaran pengoperasiannya (1). Contohnya banyak alat-alat canggih yang praktis seperti teknik monitoring jarak jauh seperti alat telemetri. Telemetri berfungsi untuk mengukur suatu objek dari jarak jauh dan hasil pengukuran tersebut dikirimkan kepada operator (2). Telemetri memberikan kemudahan dalam melakukan pengukuran dan pengiriman informasi dan sistem terbaik yang bisa digunakan untuk menyampaikan informasi serta dapat digunakan di dalam ruangan pada alat kesehatan, seperti inkubator bayi, atau infant warmer. Pada alat inkubator bayi ini suhu dan kelembaban sangat berperan penting, karena inkubator bayi ini sangat membutuhkan tingkat kehangatan yang cukup stabil untuk bayi yang prematur mengingat bayi tersebut belum terbiasa beradaptasi dengan suhu di luar kandungan sang ibu (3). Oleh sebab itu, telemetri suhu dan kelembaban sangat dibutuhkan pada alat inkubator bayi ini untuk monitoring suhu dan kelembaban bayi tersebut (4). Telemetri suhu dan kelembaban ini dapat mempermudah pelayan kesehatan di rumah sakit, mengingat permasalahan alat inkubator bayi khususnya di ruang perinatalogi yang harus mengamati lebih dekat yang mana dapat menimbulkan ketidak nyamanan dari pasien. Dari penjelasan di atas maka tujuan penelitian ini adalah membuat dan menguji suatu pemodelan alat pengukur jarak jauh atau telemetri yang dapat memantau data yang disadap oleh sensor suhu dan kelembaban kemudian dihubungkan dengan rangkaian wifi $(5,6,7)$.

\section{METODE PENELITIAN}

Pada penelitian ini dijelaskan metode yang digunakan dalam uji coba pemodelan alat telemetri suhu dan kelembaban, yaitu pengujian keluaran perancangan perangkat keras (hardware) dan perancangan perangkat lunak (software).

\section{Alat yang digunakan.}

Inkubator bayi, Alat telemetri, Alat higrometer, Alat termometer, Worksheet. 


\section{Spesifikasi}

Pada proses penelitian Uji coba rancang bangun pemodelan alat telemetri suhu dan kelembaban pada alat inkubator bayi, mempunyai spesifikasi sebagai berikut:

Tegangan Supply AC

Tegangan Supply DC Pemancar

Tegangan Supply DC Penerima

LCD

Display Output

Suhu $-40^{\circ} \mathrm{C}$ hingga $80^{\circ} \mathrm{C}$ Kelembaban $0 \%$ hingga $99,9 \%$

Dimensi pada alat pemancar

Dimensi pada alat penerima

\section{Proses pengambilan data}

Dalam proses pengambilan data dengan berpedoman kepada kerangka teori dengan langkah langkah sebagai berikut.

Alat inkubator dalam keadaan bekerja, dalam chamber inkubator diletakan alat ukur suhu dan kelembaban, dilakukan setting suhu dan monitor kelembaban dihidupkan, diletakan di dalam chamber alat telemetri transmitter dalam keadaan bekerja dan alat pembanding suhu dan kelembaban, yaitu alat Termometer dan Higrometer. Di ruang operator kebidanan diletakan alat reciever telemetri. Selanjutnya diamati kedua besaran suhu dan kelembaban pada ruang operator. Dilakukan pencatatan nilai besaran yang terdapat pada reciever telemetri. Dilakukan perbandingan nilai reciever telemetri :Rezkgyalt594z inkubator dan nilai alat :utkiy.olt

: +5 Volt

\section{:Pengolahan Data}

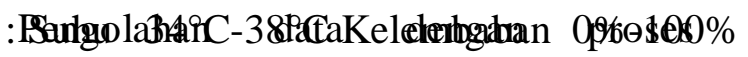
pemeriksaan data, tabulasi data, dan mengorganisir data untuk dianalisis

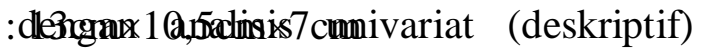

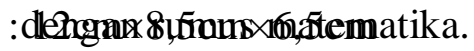

$$
\bar{x}=\sum_{i}^{n} \frac{x i}{n}
$$

dengan :

$$
\begin{aligned}
& x=\text { nilai rata-rata pengukuran } \\
& \mathrm{xi}=\text { nilai acak data pengukuran } \\
& \mathrm{x} 1, \mathrm{x} 2, \ldots . . \mathrm{xi} \\
& \mathrm{n}=\text { jumlah data yang diambil }
\end{aligned}
$$

Langkah-langkah perhitungan persentase kesalahan pada alat telemetri suhu dan kelembaban terhadap thermohygrometer pada chamber baby incubator, adalah sebagai berikut:

\section{a. Menghitung Nilai Pengukuran Berulang ( $\mathrm{x}$ ) pada baby incubator}




$$
\bar{x}=\sum_{i}^{n} \frac{x i}{n}
$$

dimana :

$\bar{x}=$ nilai rata-rata pengukuran

$\mathrm{xi}=$ nilai acak data pengukuran

$\mathrm{x} 1, \mathrm{x} 2, \ldots . \mathrm{xi}$

$\mathrm{n}=$ jumlah data yang diambil

b. Nilai kesalahan (\%)

Nilai Kesalahan $(\%)=\frac{\text { Nilai setting }- \text { Nilai rata }- \text { rata ukur }}{\text { Nilai setting }} \times 100 \%$

\section{c. Nilai Akurasi (\%)}

Nilai Akurasi $=100 \%-\%$ kesalahan

\section{HASIL DAN PEMBAHASAN}

Dalam penelitian ini akan dibahas tentang hasil dan analisa dari data pelaksanaan pengukuran suhu dan kelembaban pada baby incubator yang menggunakan alat ukur

thermohygrometer dianalisa dan dibandingkan dengan data hasil pelaksanaan pengukuran suhu dan kelembaban yang menggunakan alat ukur Telemetri Receiver. Dan hasil pengukuran tersebut akan dihitung persentase keakurasian terhadap masing-masing seting suhu dan kelembaban baik pada thermohygrometer maupun pada Telemetri Receiver suhu dan kelembaban. Kemudian dari hasil pengukuran persentase keakurasian akan dibandingkan nilai keakurasian suhu pada alat thermohygrometer pada baby incubator tersebut dengan nilai keakurasian suhu dan kelembaban pada alat Telemetri Receiver, yang dilakukan pada pada proses penelitian yang tertera di bawah ini.

Tabel 1. Hasil perhitungan \% koreksi dari pengukuran kestabilan setting suhu pada panel baby inkubator dalam menit

\begin{tabular}{|c|c|c|c|c|c|c|c|c|c|}
\hline \multirow[t]{2}{*}{ No } & \multirow{2}{*}{$\begin{array}{c}\text { Setting } \\
\text { suhu } \\
\text { Inkubator } \\
\left({ }^{\circ} \mathrm{C}\right)\end{array}$} & \multicolumn{5}{|c|}{$\begin{array}{l}\text { Hasil pengukuran pada inkubator } \\
\qquad\left({ }^{\circ} \mathrm{C}\right)\end{array}$} & \multirow[t]{2}{*}{$\begin{array}{l}\text { Rata- } \\
\text { rata }\end{array}$} & \multirow[t]{2}{*}{ Koreksi } & \multirow{2}{*}{$\begin{array}{c}\text { Percent } \\
\%\end{array}$} \\
\hline & & ukur & ukur & ukur & ukur & ukur & & & \\
\hline 1 & $33^{0} \mathrm{C}$ & 33 & 33 & 33 & 33 & 33 & & , & \\
\hline 2 & $34^{0} \mathrm{C}$ & 34 & 34 & 34 & 34 & 34 & 34 & 0 & 0 \\
\hline 3 & $35^{0} \mathrm{C}$ & 35 & 35 & 35 & 35 & 35 & 35 & 0 & 0 \\
\hline 4 & $36^{\circ} \mathrm{C}$ & 36 & 36 & 36 & 36 & 36 & 36 & 0 & 0 \\
\hline 5 & $37^{0} \mathrm{C}$ & 37 & 37 & 37 & 37 & 37 & 37 & 0 & 0 \\
\hline
\end{tabular}


Tabel 2. Hasil perhitungan \% koreksi dari pengukuran suhu dalam chamber baby incubator

\begin{tabular}{llcccccccc}
\hline & $\begin{array}{l}\text { Setting } \\
\text { suhu }\end{array}$ & \multicolumn{4}{c}{ Hasil Pengukuran pada } & \multirow{2}{*}{$\begin{array}{l}\text { Rata- } \\
\text { termometer }\left({ }^{\circ} \mathrm{C}\right)\end{array}$} & Koreksi & Percent \\
\cline { 2 - 8 } No & $\begin{array}{l}\text { Inkubator } \\
\left({ }^{\circ} \mathrm{C}\right)\end{array}$ & $\begin{array}{c}\text { ukur } \\
\text { ukur }\end{array}$ & 1 & ukur & ukur & ukur & & & $\%$ \\
\hline 1 & $33^{\circ} \mathrm{C}$ & 33,5 & 34,2 & 34,4 & 34,6 & 54,6 & 34,26 & 1,6 & 4,848 \\
2 & $34^{\circ} \mathrm{C}$ & 34,4 & 34,8 & 35,1 & 35,3 & 35,3 & 34,98 & 1,3 & 3,824 \\
3 & $35^{\circ} \mathrm{C}$ & 35,5 & 35,8 & 35,8 & 36.0 & 35,9 & 35,8 & 0,9 & 2,571 \\
4 & $36^{\circ} \mathrm{C}$ & 35,6 & 35,9 & 36.0 & 36.0 & 36.0 & 35,9 & 0,1 & 0,278 \\
5 & $37^{\circ} \mathrm{C}$ & 38,3 & 38,5 & 38,3 & 38,3 & 38,3 & 38,34 & 1,34 & 3,622 \\
\hline
\end{tabular}

Tabel 1 adalah hasil pengukuran \% koreksi kestabilan setting suhu pada baby Inkubator yang dapat menjadi acuan seting pengukuran dari setiap melakukan pengukuran suhu dan kelembaban pada alat ukur thermohygrometer dan pada alat Telemetri Receiver yang dinyatakan dalam ${ }^{\circ} \mathrm{C}$ dan $\%$.

Tabel 2 dan Tabel 3 adalah hasil $\%$ koreksi dari pengukuran suhu dan kelembaban di baby incubator dengan menggunakan alat ukur thermohygro meter yang diletakan dalam pesawat baby incubator. Ada lima pengaturan setting nilai suhu saat melakukan pengukuran suhu yaitu: setting suhu $33^{\circ} \mathrm{C}, 34^{\circ} \mathrm{C}, 35^{\circ} \mathrm{C}, 36^{\circ} \mathrm{C}$, dan $37^{\circ} \mathrm{C}$ dengan pengukuran lima kali dari setiap pengaturan setting nilai suhu. Dan pengukuran dimulai dari nilai setting terendah hingga nilai setting tertinggi yaitu dari $33^{\circ} \mathrm{C}$ hingga $37^{\circ} \mathrm{C}$

Dan juga untuk pengukuran kelembaban ada lima pengaturan setting nilai kelembaban yaitu: setting $31 \%$,

Tabel 3. Hasil perhitungan $\%$ koreksi dari pengukuran kelembaban dalam chamber baby incubator

\begin{tabular}{|c|c|c|c|c|c|c|c|c|c|}
\hline \multirow[b]{2}{*}{ No } & \multirow{2}{*}{$\begin{array}{c}\text { Setting } \\
\text { kelembaban } \\
(\%)\end{array}$} & \multicolumn{5}{|c|}{$\begin{array}{c}\text { Hasil pengukuran kelembaban } \\
\text { higrometer }(\%)\end{array}$} & \multirow[t]{2}{*}{$\begin{array}{l}\text { Rata- } \\
\text { rata }\end{array}$} & \multirow[t]{2}{*}{ Koreksi } & \multirow[t]{2}{*}{$\begin{array}{l}\text { Percent } \\
\%\end{array}$} \\
\hline & & $\begin{array}{c}\text { ukur } \\
1\end{array}$ & $\begin{array}{c}\text { ukur } \\
2\end{array}$ & $\begin{array}{c}\text { ukur } \\
3\end{array}$ & $\begin{array}{c}\text { ukur } \\
4\end{array}$ & $\begin{array}{l}\text { ukur } \\
5\end{array}$ & & & \\
\hline 1. & $51 \%$ & 51 & 49 & 47 & 46 & 45 & 47,6 & 3,4 & 6,667 \\
\hline 2. & $46 \%$ & 46 & 41 & 38 & 35 & 38 & 39,6 & 6,4 & 13,913 \\
\hline 3. & $38 \%$ & 38 & 35 & 33 & 29 & 27 & 32,4 & 5,6 & 8,947 \\
\hline 4. & $34 \%$ & 34 & 34 & 33 & 33 & 32 & 33,2 & 0,8 & 2,353 \\
\hline 5. & $31 \%$ & 31 & 31 & 27 & 27 & 24 & 28 & 3 & 9,677 \\
\hline
\end{tabular}


Tabel 4. Hasil perhitungan \% koreksi dari pengukuran suhu pada Telemetri

\begin{tabular}{|c|c|c|c|c|c|c|c|c|c|}
\hline \multirow{3}{*}{ No } & \multirow{3}{*}{$\begin{array}{l}\text { Setting } \\
\text { suhu } \\
\text { inkubator } \\
\left({ }^{\circ} \mathrm{C}\right)\end{array}$} & \multicolumn{5}{|c|}{$\begin{array}{l}\text { Hasil pengukuran pada telemetri } \\
\qquad\left({ }^{\circ} \mathrm{C}\right)\end{array}$} & \multirow[t]{3}{*}{$\begin{array}{l}\text { Rata- } \\
\text { rata }\end{array}$} & \multirow[t]{3}{*}{ Koreksi } & \multirow{3}{*}{$\begin{array}{c}\text { Percent } \\
\%\end{array}$} \\
\hline & & ukur & ukur & ukur & ukur & ukur & & & \\
\hline & & 1 & 2 & 3 & 4 & 5 & & & \\
\hline 1 & $33^{\circ} \mathrm{C}$ & 34 & 34,9 & 34,7 & 34 & 34,8 & 34,4 & 1,4 & 4,242 \\
\hline 2 & $34^{0} \mathrm{C}$ & 34,6 & 34,8 & 34,8 & 34,8 & 34,8 & 34,76 & 0,76 & 2,235 \\
\hline 3 & $35^{\circ} \mathrm{C}$ & 35 & 35,3 & 35,3 & 35,5 & 34,4 & 35,1 & 0,100 & 0,286 \\
\hline 4 & $36^{\circ} \mathrm{C}$ & 36,1 & 36,6 & 36,5 & 36,4 & 37,1 & 36,54 & 0,54 & 1,5 \\
\hline 5 & $37^{0} \mathrm{C}$ & 37 & 38,3 & 37,9 & 37,8 & 37,9 & 37,78 & 0,78 & 2,108 \\
\hline
\end{tabular}

$34 \%, \quad 38 \%, \quad 46 \%, \quad 51 \%$ dengan pengukuran lima kali dari setiap pengaturan setting nilai kelembaban dan pengukuran dimulai dari nilai setting tertinggi hingga nilai setting terendah yaitu dari $33^{\circ} \mathrm{C}$ hingga $51 \%$, $46 \%, 38 \%, 37^{\circ} \mathrm{C}, 34 \%$, hingga $31 \%$, karena suhu yang rendah menyebabkan kelembaban yang tinggi atau suhu berbanding terbalik dengan kelembaban pada pesawat baby incubator.

Pengambilan data dilakukan dengan mengamati penunjukan nilai setting alat inkubator, pada alat ukur suhu dan kelembaban atau thermohygrometer sebanyak 5 kali pengamatan, setelah nilai pada alat ukur tampil maka data langsung dicatat pada lembaran kerja dan selanjutnya dilihat lagi tampilan pada alat ukur thermohygrometer untuk setting suhu dan kelembaban berikutnya kemudian dicatat, begitu seterusnya hingga 5 kali pengamatan.

Besarnya penyimpangan dari ratarata pengukuran dijumlah dalam persen, semua pengukuran memang terjadi penyimpangan di bawah toleransi $\pm 10 \%$. kecuali pada Tabel 3 untuk setting kelembaban $46 \%$ dimana toleransinya diatas $\pm 10 \%$. Yaitu sebesar $\pm 10 \%$.yaitu $\pm 13,913 \%$.

Tabel 4 dan Tabel 5 adalah hasil $\%$ koreksi pengukuran suhu dan kelembaban dari baby incubator yang menggunakan alat ukur Telemetri Receiver yang diletakan dalam ruang perawat. Ada lima pengaturan setting nilai suhu Telemetri Receiver saat 
melakukan pengukuran suhu yaitu: setting suhu $33^{\circ} \mathrm{C}, 34^{\circ} \mathrm{C}, 35^{\circ} \mathrm{C}, 36^{\circ} \mathrm{C}$, dan $37^{\circ} \mathrm{C}$ dengan pengukuran lima kali dari setiap pengaturan setting nilai suhu. dan pengukuran dimulai dari nilai setting terendah hingga nilai setting tertinggi yaitu dari $33^{\circ} \mathrm{C}$ hingga $37^{\circ} \mathrm{C}$.

Dan juga untuk pengukuran Telemetri Receiver kelembaban ada lima pengaturan setting nilai kelembaban Telemetri Receiver yaitu: setting 31\%, 34\%, 38\%, 46\%, 51\% dengan pengukuran lima kali dari setiap pengaturan setting nilai kelembaban dan pengukuran dimulai dari nilai setting tertinggi hingga nilai setting terendah yaitu dari $33^{\circ} \mathrm{C}$ hingga $51 \%$, $46 \%, 38 \%, 37^{\circ} \mathrm{C}, 34 \%$, hingga $31 \%$, karena suhu yang rendah menyebabkan kelembaban yang tinggi atau suhu berbanding terbalik dengan kelembaban pada alat baby incubator.

Pengambilan data suhu dan kelembaban dilakukan dengan mengamati penunjukan nilai setting alat inkubator pada alat Telemetri Receiver sebanyak 5 kali pengamatan, setelah nilai pada alat ukur tampil maka data langsung dicatat pada lembaran kerja dan selanjutnya dilihat lagi tampilan suhu dan kelembaban pada alat Telemetri Receiver untuk setting suhu dan kelembaban berikutnya kemudian dicatat, begitu seterusnya hingga 5 kali pengamatan.

Besarnya penyimpangan dari ratarata pengukuran dinyatakan dalam persen, dan semua pengukuran memang terjadi penyimpangan di bawah toleransi $\pm 10 \%$. Kecuali pada tabel 4.5 untuk setting kelembaban $35,6 \%$ dan $48,3 \%$ dimana toleransinya di atas $\pm 10 \%$. Yaitu $\pm 12,528 \%$ dan $\pm 16,605$ $\%$. Toleransi kesalahan (koreksi) $\pm 10 \%$ adalah batas koreksi suhu dan kelembaban yang maksimun yang diperbolehkan dalam penggunaan alat baby incubator

\section{SIMPULAN DAN SARAN}

Uji fungsi hardware dan software alat telemetri suhu dan kelembaban dapat berjalan baik. Pada uji fungsi hasil pengukuran suhu pada termometer dalam baby incubator masih dalam ambang batas standar toleransi dibawah $10 \%$. Hasil pengukuran kelembaban hygrometer dalam baby incubator masih dalam batas standar toleransi, kecuali pada kelembaban $46 \%$ batas toleransi $13,91 \%$ Uji fungsi pengukuran suhu pada termometer Telemetri Receiver masih dalam batas standar toleransi dibawah $10 \%$. Hasil 
pengukuran kelembaban pada hygrometer Telemetri Receiver di bawah toleransi $10 \%$, kecuali pada setting kelembaban $35,6 \%$ dan $48,3 \%$ dimana batas toleransinya adalah $12,53 \%$ dan $16,61 \%$.

Dalam penggunaan alat ukur Telemetri Receiver suhu dan kelembaban pada alat baby incubator supaya digunakan pada pada lingkungan suhu,dan kelembaban yang stabil.

\section{DAFTAR PUSTAKA}

1. Departemen Kesehatan RI, Pedoman Operasional dan Pemeliharaan Peralatan Kesehatan, Jakarta : Direktorat Jenderal Pelayanan Medik Departemen Kesehatan RI, 2001.

2. Khandpur $\mathrm{R} \mathrm{S}$, Handbook of Biomedical Instrumentation, ISBN 0-07-451725-2, 1997

3. Nurcahya B, Widhiada, I.W, Subagia, I D G A, Sistem Kontrol Kestabilan Suhu Pada Inkubator Bayi Berbasis Arduino Uno Dengan Matlab/Simulink, Jurnal METTEK, 2016, Volume 2 No 1 pp $35-42$

4. Pearce E, Anatomi Fisiologi untuk Paramedis, Alih Bahasa Sri Yurdiani Handoyo, Jakarta : Gramedia. 2008.

5. Departemen Kesehatan RI, Pedoman Pengujian dan Kalibrasi Alat, Jakarta : Kesehatan Direktorat Jendral Pelayanan
Medik, 1999.

6. Jhon A. Allocca Allen Stuart, Transducers Theory \& Applications. ISBN 0-8359-7796-x, 1984.

7. Sudhir G, Element of Control System. Fanshawe College, ISBN 0-13-093255-8, 2002. 